\title{
Crises and Responsiveness: Analysing German Preference Formation During the Eurozone Crisis
}

\author{
Hanno Degner ${ }^{\mathbb{D}}$ and Dirk Leuffen $(\mathbb{D}$
}

\begin{abstract}
Do crises increase governmental responsiveness to citizens' policy demands in the European Union? Building on the responsiveness literature, we challenge the claim that well-organized business interests determine governmental preferences in times of crisis. We argue instead, that vote-seeking governments rather account for citizens' policy demands, given particularly high levels of saliency and public attention prevalent during crises. To test our theory, we analyse the formation of German governmental preferences on Economic and Monetary Union reforms during the Eurozone Crisis. We use novel data from the 'EMUChoices' project, public opinion polls as well as newspaper articles and trace the development of the German government's positioning on reforms such as the new Eurozone bailout fund or the tightening of fiscal governance rules. Our analyses show that the German government, despite intensive lobbying efforts by banks and industry associations, responded rather closely to the demands of the public. On a normative ground, this finding highlights that input legitimacy in European Union decisionmaking is stronger than oftentimes assumed, at least at the level of governmental preference formation in times of crises.
\end{abstract}

\section{Keywords}

Eurozone crisis, responsiveness, Germany, EU, Economic and Monetary Union

\section{Introduction}

Do crises increase governmental responsiveness to citizens' policy demands in the European Union (EU)? According to an orthodox reading of the liberal intergovernmentalist (LI) 'baseline model' of European integration (Moravcsik, 1993, 1998), public opinion on EU policies only plays an ancillary role in the first stage of EU decision-making, the formation of national preferences (cf. Hooghe and Marks, 2019; Schimmelfennig,

Department of Politics and Public Administration, University of Konstanz, Konstanz, Germany

\section{Corresponding author:}

Hanno Degner, Department of Politics and Public Administration, University of Konstanz, 78457 Konstanz, Germany.

Email: hanno.degner@uni-konstanz.de 
2018). Instead, LI and standard political economy literature (Grossman and Helpman, 1994) expect governments to aggregate the interests of well-organized domestic economic interest groups before heading to the supranational negotiation table. We here ask whether an unfolding crisis changes this picture? Do European governments become more responsive to citizen's policy demands when facing an urgent threat, combined with urgency and uncertainty?

To answer this question, we present two theoretical scenarios. The first one combines a conventional reading of LI with findings on crisis decision-making (Boin et al., 2005; Kingdon, 1984) and suggests that governments remain primarily responsive to economic interest groups. Crisis-induced urgency may in fact even reinforce the bias of governments' positions towards the (generally well-prepared and pre-existing) policy proposals of commercial actors. In the second scenario, we argue that under crisis conditions governments become more responsive to public opinion. To make this argument, we link LI expectations on national preference formation to insights from the responsiveness literature, which analyses why and to what extent governments or other political actors respond to (changes in) public demands. It also lays out core mechanisms, notably electoral turnover and rational anticipation, to account for this link (Mansbridge, 2003; Miller and Stokes, 1963; Soroka and Wlezien, 2010; Stimson et al., 1995; Wlezien, 1995). A number of contributions already applied such mechanisms to the EU, albeit with a predominant focus on the interstate bargaining stage of EU decision-making in the Council of Ministers (Arregui and Creighton, 2018; Hagemann et al., 2017; Wratil, 2017, 2019) and with respect to the European Parliament (Dür et al., 2015; Mahoney, 2007).

National preference formation so far has not received a lot of attention from a responsiveness perspective (cf. Judge and Thomson, 2019: 691). This is somewhat surprising, given the importance attributed to this step both in integration theory and in the normative literature, as for instance, highlighted by Bellamy's (2019: 10) 'republican intergovernmentalism'. Moreover, in light of the debate on the EU's democratic deficit (Føllesdal and Hix, 2006; Majone, 1998; Moravcsik, 2002), fuelled in recent years by critiques of executive-driven crisis management (Kreuder-Sonnen, 2016; Puntscher Riekmann and Wydra, 2013; Scharpf, 2014; Weiler, 2012), we consider this an important research gap.

We test our theory on governmental responsiveness in times of crisis with a processtracing analysis of national preference formation during the Eurozone Crisis. We select the case of Germany, the EU member state that arguably played a key role in EU decisionmaking during the crisis (Bulmer, 2014; Schimmelfennig, 2015). In particular, we analyse the German government's position taking on core reforms of the European Economic and Monetary Union (EMU), namely the institutionalization of a fiscal emergency mechanism for the Eurozone and the tightening of the EU's economic and fiscal governance rules between 2010 and 2015, capturing the two poles of the redistribution-austerity dimension which structured the EU reforms during the Eurozone crisis (cf. Lehner and Wasserfallen, 2019). In our process tracing, we use different qualitative and quantitative sources, including the 'EMU Positions' dataset (Wasserfallen et al., 2019), official governmental and parliamentary documents, opinion polls like the Politbarometer and the Eurobarometer, as well as quality newspaper articles.

Our analysis highlights that the German government indeed took public policy demands and - related to this - the position of the parliamentary majority carefully into account when formulating its positions on different reform proposals during the Eurozone crisis. In contrast, despite heavy lobbying efforts, economic interest and financial market 
actors were less able to 'impose' their views and demands on the German government. For example, the German government strongly supported a significant involvement of the private sector and the International Monetary Fund in fiscal aid programmes, a position closer to the public than to special interest groups. In our view, these findings clearly indicate the presence of responsiveness to citizens' policy demands in the phase of national preference formation.

The article is structured as follows. We start off by briefly reviewing the literatures on national preference formation and responsiveness in the EU. We identify two lines of reasoning, one focusing on responsiveness to well-organized economic interest groups, the other highlighting the conditions of responsiveness to public opinion. Against this backdrop, we formulate a theory on how crises have the potential to enhance responsiveness to citizens' policy demands in EU decision-making. We then motivate our research design, introduce our process-tracing approach and the data used for the empirical analysis. We focus on the German case, but the article ends with a more general discussion of the responsiveness of European policy-making in times of crises.

\section{Crises and Governmental Responsiveness}

Responsiveness is a central concern in both normative democratic theory (Dahl, 1971; Pitkin, 1967; Powell, 2004) and in the empirical public policy literature (Miller and Stokes, 1963; Soroka and Wlezien, 2010; Stimson et al., 1995; Wlezien, 1995). To establish responsiveness, most empirical studies link governmental policies or positions held by members of parliament or political parties to public opinion (e.g. Budge et al., 2001; Ezrow, 2010; Hobolt and Klemmensen, 2008; cf. Wlezien, 2017). Others compare the political priorities of governments with those of citizens, suggesting a positive correlation between the importance that citizens attach to policies and the political priorities of governments, for example, in the United Kingdom and the United States (Bevan and Jennings, 2014: 54; Jones et al., 2009). In a study on the European Council, Alexandrova et al. (2016) apply a similar methodology, but they only find limited evidence for agenda responsiveness.

The literature discusses a number of institutional factors that potentially moderate government responsiveness to citizens' policy demands, for instance, the electoral system (e.g. Hobolt and Klemmensen, 2008), the level of decentralization of a political system (e.g. Soroka and Wlezien, 2010), federalist arrangements (Wratil, 2019) or the 'friction' of a policy venue (Bevan and Jennings, 2014). However, a comprehensive cross-sectional study of the impact of various institutions on the opinion-policy nexus in 31 European countries by Rasmussen et al. (2018) finds only very limited evidence for institutional effects.

Just a few contributions systematically analyse how the interests and activities of (mostly economic) interest groups affect government responsiveness to public opinion. Most of them focus on the United States (Burstein, 2014; Gilens and Page, 2014; Gray et al., 2004; Lax and Phillips, 2012). In essence, they show that powerful economic interest groups have an independent effect on governmental policy (Gilens and Page, 2014; Lax and Phillips, 2012), that their preferences are usually not in line with the interests of the public majority (Gilens and Page, 2014) and that they focus their activities on a minority of the policy proposals that are (highly) salient to them (Burstein, 2014). The direction of the effect of interest group lobbying however remains contested. In their analyses of government responsiveness to citizens' demands in Switzerland and Germany, Klüver and 
colleagues (Giger and Klüver, 2016; Klüver and Pickup, 2019) find that lobbying efforts of 'sectional' economic interest groups decreases governmental responsiveness to public opinion in the two countries. By contrast, when powerful interest groups support the policy demands of the public, as Lax and Phillips (2012) show in a study of US state government responsiveness, the congruence of public opinion and government policy increases significantly. Gray et al. (2004) find a similar, yet weaker positive effect.

How does a suddenly unfolding crisis affect government responsiveness to citizens' demands? Crises are characterized as situations during which (political) systems are confronted with (1) a severe threat for material or immaterial values, (2) a sense of urgency to resolve that threat, and (3) a high degree of uncertainty about both the nature of the threat and the consequences of the political decisions taken to counter it (Boin et al., 2005; Degner, 2019). In the last decade, the presence of severe crises has become 'the new normal' for European politicians (Haughton, 2016). The resulting mass politicization and high public salience of EU policy have turned the role of public opinion in crisis decision-making into a core concern of the EU literature (Börzel and Risse, 2018; Hobolt and Wratil, 2015; Kuhn and Stoeckel, 2014; Schimmelfennig, 2018). So far, however, scholars have mainly analysed government responsiveness at the EU level, especially concerning the Council of Ministers (Arregui and Creighton, 2018; Hagemann et al., 2017; Schneider, in press; Wratil, 2017, 2019) but also the European Parliament (Dür et al., 2015; Mahoney, 2007) and the European Commission (Hartlapp et al., 2014: 235). By contrast, national preference formation on EU crisis decision-making has received less attention from a responsiveness perspective (cf. Judge and Thomson, 2019: 691). This shortcoming is surprising, because national preference formation is a key step of EU decision-making, and it is also considered important from a legitimacy standpoint, as for instance, put forward in Bellamy's (2019) republican intergovernmentalism.

In our understanding, there are two possible readings of how crises may affect government responsiveness at the stage of national preference formation. The first one is the liberal integration theoretical baseline scenario, the second one takes insights from the responsiveness literature more carefully into account. In both scenarios, we understand national preferences as 'the way [the national government] orders the possible outcomes of an interaction' on the EU level (Frieden, 1999: 42). In other words, we expect member state governments to rank the various demands of their different domestic constituencies regarding EU policy change before defending their most favourite outcome in interstate bargaining. ${ }^{1}$

According to a conventional reading of liberal intergovernmentalism (Moravcsik, 1993, 1998) and standard political economy accounts (Grossman and Helpman, 1994), well-organized commercial actors and associations - because of their strong resource endowment and informational advantages - enjoy a privileged access to utility-maximizing governments. ${ }^{2}$ National preferences on EU policy change should therefore first and foremost reflect the interests of sectional interest groups (Giger and Klüver, 2016; Klüver and Pickup, 2019). This close connection should especially hold if there are no high ratification constraints. In crises situations, economic interest groups can make effective use of their well-established channels to suggest policies to governments under high pressure to resolve the looming threat. Policy proposals are usually instantaneously available to organized interest groups, as they have already pursued them in pre-crisis times to maximize the groups' own interests (cf. Kingdon, 1984). Crisis-induced urgency may actually reinforce governments' focus on those societal actors that display expertise in the concerned area, leading to an even stronger bias of governmental positions towards those of 
specific interest groups (Boin et al., 2008: 9). To sum up, the null hypothesis expects economic interest groups to retain their strong influence on governmental preferences regarding EU policy change during crises:

H0. Governments will foremost consider the interests of well-organized economic interest groups when forming the national preference on EU policy change in crisis times.

To corroborate this hypothesis, we would need to see strong alignments between the governmental positions and the interests of organized business groups and financial market actors.

In contrast, liberal intergovernmentalism can also accommodate expectations derived from theories of economic voting (see Lewis-Beck and Nadeau, 2011) and responsiveness, including for example work by Mansbridge (2003) on 'anticipatory representation'. In our second scenario, we expect that vote- or office-seeking governments (Moravcsik, 1993, 1998; Strom and Müller, 1999) align their positions with public opinion in order to avoid being sanctioned in the next elections. The urgent threat associated with a crisis turns EU policy change into a highly salient issue for citizens, stirring high public attention for EU decision-making in the affected policy area (Degner, 2019), as well as intense party competition (Hagemann et al., 2017: 856; Hooghe and Marks, 2009). In such a setting, we expect citizens to be comparatively well informed about the issues at stake and to care strongly about the positions the government intends to defend in EU negotiations. If these positions depart from the position of the majority of the public, the government risks being sanctioned in key parliamentary votes or at the voting booth in the next elections (Lewis-Beck and Nadeau, 2011; Mansbridge, 2003). This provides governments with strong incentives to align their positions with public opinion (Carrubba, 2001; Culpepper, 2012) and to take anticipated dissent by members of parliament into account when forming the national preference (Tsebelis, 2002). Hypothesis H1 summarizes our expectations on governmental responsiveness to citizens' policy demands during crises:

H1. Governments will foremost consider citizens' policy demands when forming the national preference on EU policy change in crisis times.

\section{Methods and Data}

In the empirical part of the article, we apply process-tracing (Bennett and Checkel, 2015) as arguably the most adequate approach for a systematic in-depth investigation of the mechanisms of governmental responsiveness in the stage of national preference formation. To ensure a high internal validity of the findings, we conduct a small-n study of Germany as a substantively important case (cf. Klüver and Pickup, 2019; Schneider and Slantchev, 2018); Germany, together with France, played a major role in the EU level negotiations on EMU reforms between 2010 and 2013 (Degner and Leuffen, 2019; Schimmelfennig, 2015). Although quantitative analyses of bargaining success during the Eurozone Crisis do not depict the country as particularly successful on those issues that actually made it to the negotiation table (Degner and Leuffen, 2019; Lundgren et al., 2019), more qualitatively oriented scholars discuss the extent to which Germany acted as a (however reluctant) 'hegemon' at that time (Bulmer, 2014). With regard to the drivers 
of Germany's national preference on EMU reforms, the literature is profoundly divided. Whereas Schimmelfennig (2015) explains Germany's preferences with the country's fiscal position and the resulting material 'calculations of negative interdependence and risk', Matthijs (2016) and others (e.g. Jacoby, 2014; Schäfer, 2016) argue that ordoliberal ideas of budgetary rules and structural reform - and not material interests - account for the positions Germany defended in intergovernmental negotiations. Bulmer (2014) in turn suggests that a combination of underlying economic circumstances, ordoliberal and pro-integration ideas, institutional factors like the veto power of the Federal Constitutional Court, party politics and public Euroscepticism account for the German government's positioning during the Eurozone Crisis. In their study of the first Greek bailout package of 2010, Schneider and Slantchev (2018) show how re-election seeking governments' struggle to respond to public opinion, functional needs and political pressure from international partners at the same time but do not include business interests into their model. Our systematic analysis of governmental responsiveness to the demands of the public and economic interest groups across a broader range of contested issues adds to the rationalist strand of the evolving literature on German preference formation in crisis times.

In the following, we will link the positioning of the German government to positions taken by (1) core economic interest groups, (2) members of the German Bundestag forming the governmental majority and (3) the general public on two key EMU reforms, namely the institutionalization of a fiscal support scheme for Eurozone members and the tightening of economic and fiscal governance rules. Together, they embody the two guiding EU strategies to 'save the Euro' during the crisis, namely fiscal solidity or austerity, and financial solidarity or redistribution (cf. e.g. Lehner and Wasserfallen, 2019). In order to corroborate our theory, we must show that the government's positioning on these two reforms was closer to public opinion and the preferences of parliamentarians of the governing factions CDU/CSU and FDP, as compared to the positions of economic interest groups. Moreover, our process tracing must show that the causal mechanisms stipulated above - rising public attention, party competition and rational anticipation - were actually at work in our case.

In order to unveil these mechanisms, we first use quantitative data on newspaper coverage of the terms 'Staatsschulden' (sovereign debt), 'Fiskalpolitik' (fiscal policy) and 'Wettbewerbsfähigkeit' (competitiveness), published between February 2008 and October 2013 by two leading German quality newspapers, the Frankfurter Allgemeine Zeitung (FAZ) and the Süddeutsche Zeitung (SZ). In the light of findings of the communication science literature, which has proven a close linkage between political contestation and the intensity of media reports (Jungherr, 2014: 240-241; Wyss and Keel, 2010), we believe that this procedure allows us to measure the attention that German citizens attached to resolving the Eurozone crisis from early 2010 onwards. Second, we link the initial preferences of the German government on the most controversial issues contained in the selected proposals to the positions of both special interest groups and the broader public. To identify the initial German government's preferences in the ESM and the Fiscal Compact negotiations, we consult the 'EMU Positions' dataset (Wasserfallen et al., 2019). To analyse public opinion, we use data from the Politbarometer, ${ }^{3}$ the Eurobarometer ${ }^{4}$ and the Pew Research Centre, ${ }^{5}$ as well as parliamentary documentation ${ }^{6}$ and newspaper articles, for example, from the FAZ, the SZ, the tabloid Bild or the Financial Times. We also use newspaper articles to extract the positions of organized business groups and financial market actors. Finally, based on qualitative data gained from the 'EMU Formation' dataset, ${ }^{7}$ as well as from official governmental documents and the above-mentioned 


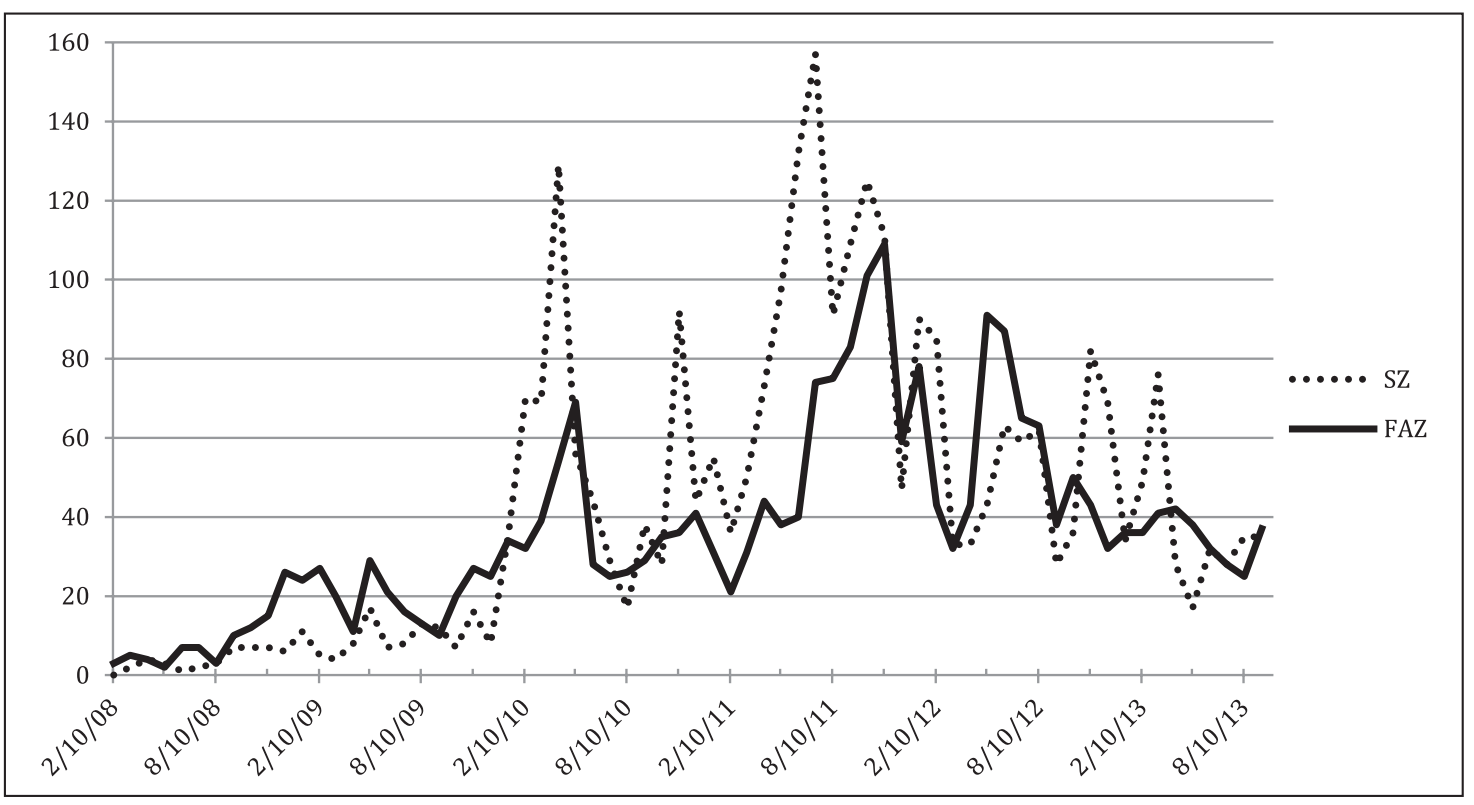

Figure I. Media Reporting on the Eurozone Crisis in Germany.

Source: own depiction. The trends show the monthly sums of articles in two newspapers (FAZ and SZ) for the term 'Staatsschulden' (sovereign debt).

newspapers, we trace the evolution of the German government's negotiation positions over time in order to determine whether it responded to public opinion rather than to interest group lobbying when accepting compromises or package deals in EU level negotiations.

\section{German Preference Formation During the Eurozone Crisis}

After the outbreak of the Eurozone Crisis in early 2010, public attention for the exposed problems of EMU increased rapidly throughout the EU (Degner, 2019). For the case of Germany, Figure 1 shows the monthly sums of articles in the FAZ and the SZ including the term 'sovereign debt', the key issue at the heart of the crisis. A first attention peak for the term 'sovereign debt' appears in May 2010, when Euro area member states granted their first financial support package to Greece and agreed to set up the temporary European Financial Stability Facility (EFSF) 2 weeks later (cf. Gocaj and Meunier, 2013). A second peak can be found in November 2010, when Ireland became the first country to ask for support from the EFSF. ${ }^{8}$

As the EU failed to agree on a permanent solution to support Greece and other debtor countries, the German as well as the European publics became increasingly worried. The year 2011 correspondingly exhibits the highest absolute attention values during the whole crisis. In July 2011, when the Euro area member states adopted the second fiscal support package for Greece, ${ }^{9}$ the FAZ published 157 monthly articles containing the term 'sovereign debt', the SZ published 74. In September 2011, the member states agreed to tighten the EU's economic and fiscal governance rules with a set of secondary legislative measures, the so-called 'Six-Pack' (Buti and Carnot, 2012). In November 2011, when the member states started the negotiations on the Fiscal Compact, ${ }^{10}$ an intergovernmental treaty that constitutionalized the Six-Pack rules for all EU members but the United 
Kingdom and the Czech Republic (Tsebelis and Hahm, 2014), 109 and 111 articles appeared in the two newspapers, respectively.

The years 2012 and 2013 are marked by a gradual decrease of public attention, albeit the number of articles remains on a higher absolute level than in pre-crisis times. Figure 1 depicts a last attention peak for the FAZ from June 2012 to July 2012, when the European Council decided to introduce a Banking Union for the Euro area ${ }^{11}$ and ECB President Draghi declared his institution's determination to do 'whatever it takes to preserve the Euro'. ${ }^{12}$ For the SZ, the graph shows minor peaks in November 2012 and March 2013, when major European Council decisions on the EU's novel Banking Union were prepared. On average, however, public attention moved downwards after the adoption of the ESM and the Fiscal Compact in February 2012.

To sum up, the overall monthly coverage of 'sovereign debt' during the crisis was three times (FAZ) or almost eight times higher (SZ) as in the 2 years before the crisis. Besides that, the two newspapers covered 'competitiveness' and 'fiscal policy' in about two times as many articles during the crisis, than in the 24 months before. Clearly, these numbers highlight that the main events and reactions to the Eurozone crisis spurred very high degrees of public attention and on this ground, we feel safe to assume that the German government's positioning on EMU reforms was carefully screened by the German public. But did the German government also take public opinion into account when formulating its preferences; or in other words, did the German government respond to citizens' demands during the Eurozone crisis?

When Greece faced state insolvency in early 2010, the majority of German citizens rejected the idea of supporting the country financially. According to a representative poll published on 26 March 2010, 68\% of German citizens opposed a German participation in a potential bailout for Greece; only $26 \%$ supported it, while $6 \%$ held no opinion. ${ }^{13}$ Three weeks earlier, on 5 March 2010, the German Bild had already addressed an open letter to the then-Greek Prime Minister Papandreou, ${ }^{14}$ criticizing Greek early retirement and 14th month pay policies, corruption and fraud of EU funds in the country. This letter, despite being harsh in tone and severely exaggerated in content, arguably expressed opinions held by a large number of German citizens.

By contrast, German banks, which were heavily invested in Greek sovereign debt bonds, ${ }^{15}$ and well-organized economic interest groups like the association of German industry (Bundesverband der Deutschen Industrie (BDI)) demanded issuing financial support to the Greek government already at that time. Whereas German banks aimed at avoiding significant losses ${ }^{16}$ and even developed concrete rescue plans in collaboration with the Greek government to this end, ${ }^{17}$ German industry focused on securing its Southern European export markets. ${ }^{18}$

In face of the intensive lobbying activities of these actors, as well as the strong political pressure exerted by its European partners, the German government reluctantly accepted establishing a joint European bailout scheme for Greece. On 11 February 2010, at an emergency European Council meeting on Greece, it agreed to 'take determined and coordinated action, if needed, to safeguard financial stability in the euro area as a whole', ${ }^{19}$ while insisting on the fact that Greece had not demanded for fiscal aid and would not need to do so in the future.

In the following weeks, in an effort to balance the German public's opposition towards supporting Greece and calls for immediate and decisive action from other EU member states, the European Central Bank (ECB), as well as German banks and industry associations (Degner and Leuffen, 2019: 102; Schneider and Slantchev, 2018: 14f), the 
government ultimately accepted limited financial support in the form of bilateral loans, albeit on the condition that Greece would adopt comprehensive fiscal and economic reforms. This position, which was reflected in a statement by the Euro area heads of state and government of 25 March 2010, ${ }^{20}$ was taken to reassure the public that the government would stand firmly against the introduction of a 'transfer union' in the EU. ${ }^{21}$

After Greece eventually requested European support on 23 April 2010 in view of an imminent fiscal default, the German government - facing electoral pushback in important regional elections in North Rhine-Westphalia (Schneider and Slantchev, 2018) - delayed its agreement to activate the meanwhile prepared financial support scheme for the country until 3 May 2010. On that day, in order to avoid the potentially disastrous economic and political consequences of a Greek default for Germany and the EU as a whole, about $65 \%$ of Bundestag members supported the government's legislative proposal that allowed for the issuing of up to $€ 110$ billion to Greece, with a German share of $€ 22.4$ billion in bilateral loans. $^{22}$

In the following days, when the interest rates of other Southern European debt bonds rose to endangering heights, the government continued to oppose a French proposal for the set up of a more encompassing, yet temporary emergency mechanism for the whole Euro area, the EFSF. It was not before 7 May 2010, election day in the large state of North Rhine Westphalia (Schneider and Slantchev, 2018: 20ff), that the German government ceased its opposition to issuing loan guarantees of up to $€ 123$ billion within the EFSF framework. Reportedly, French President Sarkozy had threatened Chancellor Merkel with abandoning the Euro in case Germany would not lift its opposition to the EFSF (Schimmelfennig, 2015: 187), highlighting the pressure under which Merkel accepted an outcome that clearly diverged from her - and the general public's - preference. The Bundestag adopted the corresponding law, which allowed for Germany's participation in the EFSF, on 21 May 2010. Moreover, 319 members of the ruling CDU/CSU and FDP factions supported the governmental proposal, while 268 MPs from the opposition parties - but also 10 members of CDU, CSU and FDP - abstained or voted against the introduction of the EFSF (Degner and Leuffen, 2016).

Acknowledging the timing and especially the slowing down of decision-making, we find that the German government displayed a strong awareness of public opinion when formulating its positions on fiscal aid for Eurozone countries in the first months of 2010. Although the ultimate outcome at the EU level - fiscal support for Greece and others in exchange for comprehensive economic and fiscal policy reforms - was closer to the position of the German industry and bank associations, in our process tracing we were unable to find supporting evidence for the mechanisms postulated by conventional LI or political economy accounts. Instead of following interest group blueprints, the German government initially followed public opinion. Only over time - and after it was confronted with strong political pressures from its European partners - it relaxed its rigid positions, moving in the direction initially already demanded by German economic interest groups.

Despite Chancellor Merkel's strong efforts to convince the public that the compromise struck with its European partners - supporting Greece and setting up the EFSF in exchange for comprehensive domestic reforms and stricter European rules on economic and fiscal governance - would ultimately serve the German national interest, voters still responded negatively to the lack of congruence between its position and the adopted measures. The Chancellor's conservative party for instance lost the elections in North Rhine-Westphalia on 7 May 2010 by a landslide and public support for the CDU across Germany fell to a 
low of $31 \%$ by June $2010 .{ }^{23}$ Support for Merkel personally fell by more than $18 \%$ to an all-time low at this same time. ${ }^{24}$

Between mid-May 2010 and February 2012, no major elections took place on the federal or the states level. ${ }^{25}$ During that time, Germany negotiated the transformation of the temporary EFSF into a permanent European Stability Mechanism (ESM) with its fellow Eurozone partners, in exchange for the adoption of far-reaching reforms of the EU's system of fiscal governance. Or, in the words of the Financial Times, ${ }^{26}$ 'if Germany's original vision of the Eurozone - no bailouts, no shared debts and, in some quarters, no Greece - was becoming unachievable, Berlin was going to ensure that shared burdens came with centralized control'. The main contested issues in these negotiations, according to the EMU Positions dataset (Wasserfallen et al., 2019), concerned the ESM's size, scope and sources, as well as the extent to which the EU's fiscal rules were to be sharpened. To restore its public support, the government continued to focus on citizens' demands when formulating the national preference. Thus, in response to lasting public opposition towards increasing fiscal redistribution in the Euro area - in December 2010,62\% of the German population still opposed granting financial support to other Eurozone member states, while only $32 \%$ were in favour ${ }^{27}$ - the German government clearly positioned itself at the extreme end of the preference spectrum, insisting on limiting ESM lending capacity to $€ 500$ billion (the combined capacity of the already existing EFSF and the European Financial Stability Mechanism (EFSM)), on the limitation of ESM sources to guarantees of participating member states, paid-in capital and money raised from fines that countries in breach of the stability and growth pact would have to pay, and on the restriction of ESM aid to Eurozone governments but not for example, private banks. Moreover, Germany demanded for ESM aid to be conditional on the ratification of and compliance with the Fiscal Compact, including the introduction of debt brakes in the national constitutions of Euro area member states, the mandatory and significant involvement of the private sector in future aid programmes and a limited role of supranational actors in the institution. Finally, the government ardently rejected the introduction of Eurobonds as a substitute for the ESM but instead demanded for the introduction of a financial transaction tax (FTT) to reduce financial market speculations and make the financial sector contribute to the costs of the crisis resolution since the outbreak of the World Financial Crisis in 2008.

Especially the latter two positions aligned well with the German public. In November 2011, shortly before the Eurozone member states agreed upon the ESM and the Fiscal compact treaty, a representative poll found that $79 \%$ of the German population rejected Eurobonds, while only 15 expressed their support for this measure. ${ }^{28}$ In turn, $80 \%$ of the population supported the introduction of a special tax for banks in March 2010, ${ }^{29}$ and $58 \%$ favoured the introduction of a FTT in January 2012. ${ }^{30}$ The positions of well-organized German business interests, by contrast, diverged substantively on these issues. In July 2011, for instance, the BDI reiterated its demand for a combined debt restructuring and investment programme for Greece, ${ }^{31}$ which was rather unpopular among the German population. ${ }^{32}$ The German public constantly expressed its opposition towards debt restructuring (Mody, 2018: 275). On 17 May 2011, Chancellor Merkel correspondingly reiterated 'her strong opposition to restructuring debt in any member state of the Eurozone, contradicting speculation that Germany was pushing such a solution in Greece' ${ }^{33}$ Only when a restructuring of the Greek debt became unavoidable due to rising functional constraints and strong political pressures exerted most notably the IMF and the French government, the German government dropped its resistance and agreed to a haircut on the 
Greek debt in July 2011 (Zettelmeyer et al., 2013: 5). In our view, this development should not, in principle, be considered a shift of the German government's ideal positions but rather its readiness to accept presumably unavoidable outcomes negotiated at the European level.

Again, the conventional expectation, taken up by hypothesis $\mathrm{H} 0$, would have expected an early governmental positioning in line with the preferences of well-organised interest groups. If we consider the BDI the most prominent representative of German business, the government should have favoured supporting Greece through a haircut and an investment programme. But this is not what we find in the decision-making process. Instead, the government closely followed public opinion as long as possible, against mounting pressures from its international partners. In a similar vein, the German government effectively ignored that German industry associations repeatedly rejected the idea of a FTT ${ }^{34}$ or expressed reluctance towards the strong involvement of the IMF in fiscal aid programmes for Euro area members. ${ }^{35}$

Of course, on a range of issues economic interest groups and the German public displayed essentially the same interests. This makes it difficult to evaluate the predictive qualities of our competing hypotheses. For example, the BDI, the Association of German Chambers of Commerce and Industry, and the association of German exporters already demanded for tighter fiscal rules, sanctions for breaches of the EU' stability and growth pact and the introduction of debt brakes in the respective national constitutions of Euro area member states in June 2010. ${ }^{36}$ In March 2011, they expressed their opposition towards a 'transfer union' and Eurobonds 'at the current state of European integration'. ${ }^{37}$ Interestingly, however, not all major industrial associations maintained this position over the course of the crisis. In August 2011, German exporters repeatedly called for the introduction of such common debt bonds in order to 'issue a strong statement to the financial markets' ${ }^{38}$ Differences among major economic interest groups had already become visible in December 2010, when the BDI criticized the German banking sector for failing to offer constructive input on how to stabilize the Euro area. Such conflicts arguably undermined the influence of business interests on governmental position taking when, as highlighted above, public opinion and business interests diverged.

The fact that public opinion polls show strong support (relative and absolute) for the government's handling of the Eurozone Crisis in March/April 2012, that is, after adoption of ESM and Fiscal Compact on 2 February 2012 again underlines that the German public felt to be well represented by its government. The Pew Research Global Attitudes report notes that ' $80 \%$ of Germans thought Chancellor Angela Merkel had done a good job as an economic manager' ${ }^{39}$ Thus, although the government did not achieve all its goals in the EU level negotiations (Degner and Leuffen, 2019), citizens apparently recognized that their preferences were well represented in the German negotiation positions.

\section{Conclusion}

The conventional political economy literature maintains that organized business groups and financial market actors largely determine governmental preferences. In this article, we contrast this view. Our analysis of national preference formation in Germany during the Eurozone Crisis suggests that the demands of citizens were strongly taken into account by the German government when formulating its positions on key EMU questions. When in disagreement, the German government - fully aware of the public's attention and concerns about the Eurozone Crisis - followed the public rather than business groups. That 
business interests later on in the process repeatedly found its ways into European outcomes, is a result more of European negotiation dynamics, positions taken by other EU member states, as well as structural constraints imposed by the crisis, rather than the positions defended by the German government.

While the empirical focus of this article is on the case of Germany, we believe that our findings should similarly apply to other countries, as well. In fact, we have no reasons to doubt that EMU rescue measures were not as hotly debated in the debtor states. With respect to European integration more generally, the pattern corresponds to the post-functionalist logic put forward by Hooghe and Marks (2009). ${ }^{40}$ In our case, the German public's position was tantamount to a 'constraining dissensus' for saving EMU. The recent failure of the City of London to prevent Brexit and shape the British government's negotiation positions on that issue (James and Quaglia, 2019) most prominently highlights that economically powerful interest groups may not prevail in EU politics more generally. Examples such as these underline the external validity of our claim that governments are increasingly responsive to citizens' demands in times of crises.

Whether national positions translate to political outputs at the European level largely depends on interstate bargaining, the second step of regional integration models. Therefore, perceived mismatches between what individual member state publics want and actual EU negotiation outputs, are not to be attributed to a lack of responsiveness to citizens' demands on the parts of national governments but rather - almost naturally result from an aggregation of heterogeneous national preferences. Clearly, serving only particular nations' interests cannot be the EU's mission and from a democratic theory point of view, it is primarily important that the process of European preference aggregation is designed and conducted according to justifiable principles of legitimacy (more generally on the issue of representation cf. Powell, 2004). Yet, based on our findings, we conclude that input legitimacy in EU decision-making is stronger than oftentimes assumed in the public discourse and in parts of the academic literature, at least at the level of governmental preference formation in times of crises.

\section{Acknowledgements}

For helpful comments on earlier versions of this article, we thank Christian Breunig, Cecilia Sottilotta, the audiences of the EMU Choices conference in Stockholm (September 2018) and the PACTE research seminar at Sciences Po Grenoble (October 2018), as well as three anonymous reviewers. The usual disclaimers apply.

\section{Funding}

The author(s) disclosed receipt of the following financial support for the research, authorship, and/or publication of this article: This work received financial support from the Research Executive Agency of the European Commission (Horizon 2020 Grant 649532).

\section{ORCID iDs}

Hanno Degner iD https://orcid.org/0000-0003-0077-8819

Dirk Leuffen (iD) https://orcid.org/0000-0002-0419-387X

\section{Notes}

1. As we refer to the concept of observed preferences (Frieden, 1999: 57), we use the term (policy) 'positions' synonymously to 'preferences' (cf. Wasserfallen et al., 2019: 13).

2. We here speak of a 'conventional' reading of liberal intergovernmentalism because already Moravcsik (1993) acknowledges that the domestic stakeholders should vary over policy areas (cf. also Moravcsik, 2018).

3. Available at: http://www.forschungsgruppe.de/Umfragen/Politbarometer/ (accessed 1 July 2018).

4. Available at: http://ec.europa.eu/commfrontoffice/publicopinion/index.cfm (accessed 1 July 2018). 
5. Available at: http://www.pewglobal.org/datasets/ (accessed 1 July 2018).

6. Available at: https://www.bundestag.de/dokumente/protokolle/plenarprotokolle (accessed 1 July 2018).

7. The data will be made available in mid-2019. For more information, see https://emuchoices.eu/data/ (accessed 1 March 2019).

8. The Guardian, 28 November 2010, Available at: http://www.theguardian.com/business/ireland-businessblog-with-lisa-ocarroll/2010/nov/28/ireland-bailout-full-government-statement (accessed 20 January 2015).

9. See the Statement of the Heads of State and Government of the Euro Area and EU Institutions, 21 July 2011, Available at: http://europa.eu/rapid/press-release_DOC-11-5_en.htm?locale=de (accessed 20 January 2015).

10. See the Press statement by European Council President Van Rompuy, 9 December 2011, Available at: http://europa.eu/rapid/press-release_PRES-11-488_en.htm?locale=en (accessed 20 January 2015).

11. See European Commission MEMO 12/656, 10 September 2012, Available at: http://europa.eu/rapid/ press-release_MEMO-12-656_en.htm (accessed 20 January 2015).

12. See https://www.ecb.europa.eu/press/key/date/2012/html/sp120726.en.html (accessed 1 July 2018).

13. See http://www.forschungsgruppe.de/Umfragen/Politbarometer/Archiv/Politbarometer_2010/Maerz_II/ (accessed 1 July 2018).

14. Find the translated letter in The Guardian, 5 March 2010, Available at: https://www.theguardian.com/ business/2010/mar/05/bild-open-letter-greece-papandreou (accessed 1 July 2018).

15. The banking sectors of Germany and France together accounted for an exposure of 119 billion Dollar to Greece in February 2010. Wall Street Journal, 17 February 2010, Available at: http://on.wsj.com/1nWbEKf (accessed 30 September 2014).

16. SZ, 18 March 2010, p. 25: 'Ackermann für Rettung der Griechen'.

17. Deutsche Bank staff met the Greek finance minster in Athens on 4 February 2010 with the aim to develop a joint European rescue scheme for the country. Deutsche Bank Chairman Josef Ackermann presented the plan to the German Chancellery on 26 February 2010. See DIE ZEIT, 26 May 2010, Available at: http:// bit.ly/Tie4pK (accessed 30 September 2014).

18. See SZ, 6 March 2010, p. 24: 'Von Kritikern umgeben; Mächtige Wirtschaftsbosse verstärken den Druck auf Bundeskanzlerin Angela Merkel und fordern ein Ende des Zögerns'.

19. See https://www.consilium.europa.eu/media/20485/112856.pdf (accessed 1 July 2018).

20. See https://www.consilium.europa.eu/media/21429/20100325-statement-of-the-heads-of-state-or-governmentof-the-euro-area-en.pdf (accessed 1 July 2019).

21. See https://www.bundesregierung.de/ContentArchiv/DE/Archiv17/Regierungserklaerung/2010/2010-0519-merkel-erklaerung-eu-stabilisierungsmassnahmen.html (accessed 31 December 2017).

22. See https://www.bundestag.de/dokumente/textarchiv/2010/29673660_kw18_de_griechenland_2/201688 (accessed 1 July 2018).

23. See http://www.forschungsgruppe.de/Umfragen/Politbarometer/Langzeitentwicklung_-_Themen_im_ Ueberblick/Politik___Archiv/ (accessed 1 July 2018).

24. It took the Chancellor more than 2 years to recover from this plunge and her party even longer (cf. Hennessy, 2017: 7; Schneider and Slantchev, 2018: 19).

25. The most important regional elections took place in the Land of Baden-Württemberg on 27 March 2011. Yet, only 11 million citizens or less than $15 \%$ of the total German population live there.

26. See https://www.ft.com/content/b4e2e140-d9c3-11e3-920f-00144feabdc0 (accessed 1 July 2018).

27. See http://www.forschungsgruppe.de/Umfragen/Politbarometer/Archiv/Politbarometer_2010/Dezember_ II/ (accessed 1 July 2018).

28. See http://www.forschungsgruppe.de/Umfragen/Politbarometer/Archiv/Politbarometer_2011/November II/ (accessed 1 July 2018).

29. See http://www.forschungsgruppe.de/Umfragen/Politbarometer/Archiv/Politbarometer_2010/Maerz II/

30. See http://www.forschungsgruppe.de/Umfragen/Politbarometer/Archiv/Politbarometer_2012/ Januar_I_2012/

31. FAZ, 16 July 2011, 'SPD fordert europäischen Finanzminister'.

32. See http://www.forschungsgruppe.de/Umfragen/Politbarometer/Archiv/Politbarometer_2011/Oktober_I/ (accessed 1 July 2018).

33. See https://www.ft.com/content/60525444-7fe4-11e0-b018-00144feabdc0 (accessed 20 June 2018).

34. FAZ, 22 March 2010, 'Koalition will Banken an Kosten der Krise beteiligen'. FAZ, 1 April 2010, p. 11: 'Banken sollen die Abgabe doch nicht von der Steuer absetzen dürfen'.

35. FAZ, 2 March 2010, Available at: http:/www.faz.net/aktuell/wirtschaft/wirtschaftspolitik/im-gespraechbdi-chef-keitel-seit-der-wahl-herrscht-orientierungslosigkeit-1953521.html (accessed 1 July 2018).

36. FAZ, 15 June 2010, p. 13: 'Arbeitgeber für mehr gemeinsame Haushaltspolitik'. 
37. FAZ, 7 March 2011, p. 11: 'Wirtschafts warnt vor Schuldenunion'.

38. FAZ, 24 August 2011, p. 10: 'Streitereien über Goldpfand und Eurobonds'.

39. See http://assets.pewresearch.org/wp-content/uploads/sites/2/2012/05/Pew-Global-Attitudes-ProjectEuropean-Crisis-Report-FINAL-FOR-PRINT-May-29-2012.pdf (accessed 1 July 2018).

40. Note, that from an integration theoretical perspective, liberal intergovernmentalism's core theoretical assumptions of utility-maximizing governmental actors are not at all violated by our findings. More recently, this opening to public opinion has also been acknowledged by Moravcsik (2018).

\section{References}

Alexandrova P, Rasmussen A and Toshkov D (2016) Agenda Responsiveness in the European Council: Public Priorities, Policy Problems and Political Attention. West European Politics 39: 605-627.

Arregui J and Creighton MJ (2018) Public Opinion and the Shaping of Immigration Policy in the European Council of Ministers. Journal of Common Market Studies 56: 1323-1344.

Bellamy R (2019) A Republican Europe of States: Cosmopolitanism, Intergovernmentalism and Democracy in the EU. Cambridge: Cambridge University Press.

Bennett A and Checkel JT (2015) Process Tracing: From Philosophical Roots to Best Practices. In: Bennett A and Checkel JT (eds) Process Tracing: From Metaphor to Analytic Tool. Cambridge: Cambridge University Press, pp.1-37.

Bevan S and Jennings W (2014) Representation, Agendas and Institutions. European Journal of Political Research 53: 37-56.

Boin A, McConnell A and 't Hart P (2008) Governing After Crisis: The Politics of Investigation, Accountability and Learning. Cambridge: Cambridge University Press.

Boin A, 't Hart P, Stern E, et al. (2005) The Politics of Crisis Management: Public Leadership Under Pressure. Cambridge: Cambridge University Press.

Börzel TA and Risse T (2018) From the Euro to the Schengen Crises: European Integration Theories, Politicization, and Identity Politics. Journal of European Public Policy 25: 83-108.

Budge I, Klingemann H-D, Volkens A, et al. (2001) Mapping Policy Preferences: Estimates for Parties, Electors, and Governments 1945-1998. Oxford: Oxford University Press.

Bulmer SJ (2014) Germany and the Eurozone Crisis: Between Hegemony and Domestic Politics. West European Politics 37: 1244-1263.

Burstein P (2014) American Public Opinion, Advocacy, and Policy in Congress: What the Public Wants and What It Gets. New York: Cambridge University Press.

Buti M and Carnot N (2012) The EMU Debt Crisis: Early Lessons and Reforms. Journal of Common Market Studies 50: 899-911.

Carrubba CJ (2001) The Electoral Connection in European Union Politics. The Journal of Politics 63: 141-158.

Culpepper PD (2012) Quiet Politics and Business Power: Corporate Control in Europe and Japan. Cambridge: Cambridge University Press.

Dahl R (1971) Polyarchy: Participation and Opposition. New Haven, CT: Yale University Press.

Degner H (2019) Public Attention, Governmental Bargaining, and Supranational Activism: Explaining European Integration in Response to Crises. Journal of Common Market Studies 57: 242-259.

Degner H and Leuffen D (2016) Keynes, Friedman, or Monnet? Explaining Parliamentary Voting Behaviour on Fiscal Aid for Euro Area Member States. West European Politics 39: 1139-1159.

Degner H and Leuffen D (2019) The Role of France and Germany in the Rescuing of the Eurozone. European Union Politics 20: 89-108.

Dür A, Bernhagen P and Marshall D (2015) Interest Group Success in the European Union: When (and Why) Does Business Lose? Comparative Political Studies 48: 951-983.

Ezrow L (2010) Linking Citizens and Parties: How Electoral Systems Matter for Political Representation. Oxford: Oxford University Press.

Føllesdal A and Hix S (2006) Why There Is a Democratic Deficit in the EU: A Response to Majone and Moravcsik. Journal of Common Market Studies 44: 533-562.

Frieden JA (1999) Actors and Preferences in International Relations. In: Lake DA and Powell R (eds) Strategic Choice and International Relations. Princeton, NJ: Princeton University Press, pp.39-76.

Giger N and Klüver H (2016) Voting Against Your Constituents? How Lobbying Affects Representation. American Journal of Political Science 60: 190-205.

Gilens M and Page BI (2014) Testing Theories of American Politics: Elites, Interest Groups, and Average Citizens. Perspectives on Politics 12: 564-581.

Gocaj L and Meunier S (2013) Time Will Tell: The EFSF, the ESM, and the Euro Crisis. Journal of European Integration 35: 239-253. 
Gray V, Lowery D, Fellowes M, et al. (2004) Public Opinion, Public Policy, and Organized Interests in the American States. Political Research Quarterly 57: 411-420.

Grossman GM and Helpman E (1994) Protection for Sale. The American Economic Review 84: 833-850.

Hagemann S, Hobolt SB and Wratil C (2017) Government Responsiveness in the European Union: Evidence from Council Voting. Comparative Political Studies 50: 850-876.

Hartlapp M, Metz J and Rauh C (2014) Which Policy for Europe? Power and Conflict Inside the European Commission. Oxford: Oxford University Press.

Haughton T (2016) Is Crisis the New Normal? The European Union in 2015. Journal of Common Market Studies 54: 5-7.

Hennessy A (2017) Good Samaritans vs. Hardliners: The Role of Credible Signalling in Greek Bailout Negotiations. JCMS: Journal of Common Market Studies 55: 744-761.

Hobolt SB and Klemmensen R (2008) Government Responsiveness and Political Competition in Comparative Perspective. Comparative Political Studies 41: 309-337.

Hobolt SB and Wratil C (2015) Public Opinion and the Crisis: The Dynamics of Support for the Euro. Journal of European Public Policy 22: 238-256.

Hooghe L and Marks G (2009) A Postfunctionalist Theory of European Integration: From Permissive Consensus to Constraining Dissensus. British Journal of Political Science 39: 1-23.

Hooghe L and Marks G (2019) Is Liberal Intergovernmentalism Regressive? A comment on Moravcsik (2018). Journal of European Public Policy 26: 1-8.

Jacoby W (2014) The Politics of the Eurozone Crisis. Two Puzzles Behind the German Consensus. German Politics \& Society 32: 70-85.

James S and Quaglia L (2019) Brexit, the City and the Contingent Power of Finance. New Political Economy 24: 258-271.

Jones BD, Larsen-Price H and Wilkerson J (2009) Representation and American Governing Institutions. The Journal of Politics 71: 277-290.

Judge A and Thomson R (2019) The Responsiveness of Legislative Actors to Stakeholders' Demands in the European Union. Journal of European Public Policy 26: 676-695.

Jungherr A (2014) The Logic of Political Coverage on Twitter: Temporal Dynamics and Content. Journal of Communication 64: 239-259.

Kingdon JW (1984) Agendas, Alternatives, and Public Policies. Boston, MA: Little, Brown and Company.

Klüver H and Pickup M (2019) Are They Listening? Public Opinion, Interest Groups and Government Responsiveness. West European Politics 42: 91-112.

Kreuder-Sonnen C (2016) Beyond Integration Theory: The (Anti-)Constitutional Dimension of European Crisis Governance. Journal of Common Market Studies 54: 1350-1366.

Kuhn T and Stoeckel F (2014) When European Integration Becomes Costly: The Euro Crisis and Public Support for European Economic Governance. Journal of European Public Policy 21: 624-641.

Lax JR and Phillips JH (2012) The Democratic Deficit in the States. American Journal of Political Science 56: 148-166.

Lehner T and Wasserfallen F (2019) Contestation in the Reform of the Eurozone. European Union Politics 20: 45-64.

Lewis-Beck MS and Nadeau R (2011) Economic Voting Theory: Testing New Dimensions. Electoral Studies 30: 288-294.

Lundgren M, Bailer S, Dellmuth LM, et al. (2019) Bargaining Success in the Reform of the Eurozone. European Union Politics 20 (1): 65-88

Mahoney C (2007) Lobbying Success in the United States and the European Union. Journal of Public Policy 27: $35-56$.

Majone G (1998) Europe's 'Democratic Deficit': The Question of Standards. European Law Journal 17: 5-28.

Mansbridge J (2003) Rethinking Representation. American Political Science Review 97: 515-528.

Matthijs M (2016) Powerful Rules Governing the Euro: The Perverse Logic of German Ideas. Journal of European Public Policy 23: 375-391.

Miller WE and Stokes DE (1963) Constituency Influence in Congress. American Political Science Review 57: 45-56.

Mody A (2018) Euro Tragedy: A Drama in Nine Acts. Oxford: Oxford University Press.

Moravcsik A (1993) Preferences and Power in the European Community: A Liberal Intergovernmentalist Approach. Journal of Common Market Studies 31: 473-524.

Moravcsik A (1998) The Choice for Europe: Social Purpose and State Power from Messina to Maastricht. Ithaca, NY: Cornell University Press.

Moravcsik A (2002) In Defense of the 'Democratic Deficit': Reassessing Legitimacy in the European Union. Journal of Common Market Studies 40: 603-624. 
Moravcsik A (2018) Preferences, Power and Institutions in 21st-Century Europe. Journal of Common Market Studies 56: 1648-1674.

Pitkin HF (1967) The Concept of Representation. Berkeley, CA: University of California Press.

Powell GB (2004) The Chain of Responsiveness. Journal of Democracy 15: 91-105.

Puntscher Riekmann S and Wydra D (2013) Representation in the European State of Emergency: Parliaments Against Governments? Journal of European Integration 35: 565-582.

Rasmussen A, Reher S and Toshkov D (2018) The Opinion-Policy Nexus in Europe and the Role of Political Institutions. European Journal of Political Research 57: 1-23.

Schäfer D (2016) A Banking Union of Ideas? The Impact of Ordoliberalism and the Vicious Circle on the EU Banking Union. Journal of Common Market Studies 54: 961-980.

Scharpf FW (2014) Political Legitimacy in a Non-Optimal Currency Area. In: Cramme O and Hobolt SB (eds) Democratic Politics in a European Union Under Stress. Oxford: Oxford University Press, pp.19-47.

Schimmelfennig F (2015) Liberal Intergovernmentalism and the Euro Area Crisis. Journal of European Public Policy 22: 177-195.

Schimmelfennig F (2018) Liberal Intergovernmentalism and the Crises of the European Union. Journal of Common Market Studies 56: 1578-1594.

Schneider CJ (in press) Public Commitments as Signals of Responsiveness in the European Union. The Journal of Politics 82. Available at: https:/quote.ucsd.edu/cjschneider/files/2018/11/JOP-Commitment-final.pdf (accessed 1 June 2019).

Schneider CJ and Slantchev BL (2018) The Domestic Politics of International Cooperation: Germany and the European Debt Crisis. Internationale Organization 72: 1-31.

Soroka SN and Wlezien C (2010) Degrees of Democracy: Politics, Public Opinion, and Policy. New York: Cambridge University Press.

Stimson JA, MacKuen MB and Erikson RS (1995) Dynamic Representation. American Political Science Review 89: 543-565.

Strom K and Müller WC (1999) Political Parties and Hard Choices. In: Müller WC and Strom K (eds) Policy, Office, or Votes? How Political Parties in Western Europe Make Hard Decisions. Cambridge: Cambridge University Press, pp.1-35.

Tsebelis G (2002) Veto Players. Princeton, NJ: Princeton University Press.

Tsebelis G and Hahm H (2014) Suspending Vetoes: How the Euro Countries Achieved Unanimity in the Fiscal Compact. Journal of European Public Policy 21: 1388-1411.

Wasserfallen F, Leuffen D, Kudrna Z, et al. (2019) Introduction: Studying Decision-Making During the Eurozone Crisis with New Data. European Union Politics 20: 3-23.

Weiler JHH (2012) In the Face of the Crisis: Input Legitimacy, Output Legitimacy and the Political Messianism of European Integration. Journal of European Integration 34: 825-841.

Wlezien C (1995) The Public as Thermostat: Dynamics of Preferences for Spending. American Journal of Political Science 39: 981-1000.

Wlezien C (2017) Public Opinion and Policy Representation: On Conceptualization, Measurement, and Interpretation. Policy Studies Journal 45: 561-582.

Wratil C (2017) Modes of Government Responsiveness in the European Union: Evidence from Council Negotiation Positions. European Union Politics 19: 52-74.

Wratil C (2019) Territorial Representation and the Opinion-Policy Linkage: Evidence from the European Union. American Journal of Political Science 63: 197-211.

Wyss V and Keel G (2010) Journalismusforschung. In: Bonfadelli H, Jarren O and Bonfadelli H (eds) Einführung in die Publizistikwissenschaft. 3. Auflage. Bern: Haupt, pp.337-378.

Zettelmeyer J, Trebesch C and Gulati M (2013) The Greek Debt Restructuring: An Autopsy. Paper Presented at the Fifty-Seventh Economic Policy Panel Meeting, Dublin, 19-20 April.

\section{Author Biographies}

Hanno Degner is a Postdoctoral researcher at the Department of Politics and Public Administration, University of Konstanz. His research interests include the interplay of crises and European integration in various policy areas, but in particular in the European Economic and Monetary Union.

Dirk Leuffen is Professor of Political Science and International Politics, Department of Politics and Public Administration, University of Konstanz. His research interests include the study of (differentiated) European integration, decision-making in the European Union and more generally the interplay between domestic and international politics. 